\title{
Surface lime and silicate application and crop production system effects on physical characteristics of a Brazilian Oxisol
}

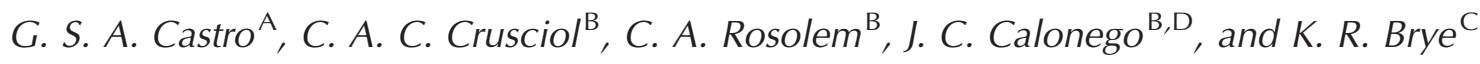 \\ AEmbrapa Monitoramento por Satélite, Av. Soldado Passarinho, no. 303, Fazenda Jardim Chapadão, \\ 13070-115, Campinas, São Paulo, Brazil. \\ ${ }^{B}$ São Paulo State University (UNESP), College of Agronomic Sciences, Rua José Barbosa de Barros, \\ no. 1780, 18603-970, Botucatu, São Paulo, Brazil. \\ CUniversity of Arkansas, Department of Crop, Soil, Environmental Sciences, Fayetteville, AR 72701, USA. \\ ${ }^{\mathrm{D} C o r r e s p o n d i n g}$ author. Email: juliano@fca.unesp.br
}

\begin{abstract}
This work aimed to evaluate the effects of crop rotations and soil acidity amelioration on soil physical properties of an Oxisol (Rhodic Ferralsol or Red Ferrosol in the Australian Soil Classification) from October 2006 to September 2011 in Botucatu, SP, Brazil. Treatments consisted of four soybean (Glycine max)-maize (Zea mays)-rice (Oryza sativa) rotations that differed in their off-season crop, either a signal grass (Urochloa ruziziensis) forage crop, a second crop, a cover crop, or fallow. Two acid-neutralising materials, dolomitic lime (effective calcium carbonate equivalent $(\mathrm{ECCE})=90 \%)$ and calcium-magnesium silicate $(\mathrm{ECCE}=80 \%)$, were surface applied to raise the soil's base saturation to $70 \%$. Selected soil physical characteristics were evaluated at three depths $(0-0.1,0.1-0.2$, and $0.2-0.4 \mathrm{~m})$. In the top $0.1 \mathrm{~m}$, soil bulk density was lowest $(P<0.05)$ and macroporosity and aggregate stability index were greatest $(P<0.05)$ in the forage crop compared with all other production systems. Also, bulk density was lower $(P<0.05)$ and macroporosity was greater $(P<0.05)$ in the acid-neutralising-amended than the unamended control soil. In the $0.1-0.2-\mathrm{m}$ interval, mean weight diameter and mean geometric diameter were greater $(P<0.05)$ in the forage crop compared with all other production systems. All soil properties evaluated in this study in the $0.2-0.4-\mathrm{m}$ interval were unaffected by production system or soil amendment after five complete cropping cycles. Results of this study demonstrated that certain soil physical properties can be improved in a no-tillage soybean-maize-rice rotation using a forage crop in the off-season and with the addition of acid-neutralising soil amendments. Any soil and crop management practices that improve soil physical properties will likely contribute to sustaining long-term soil and crop productivity in areas with highly weathered, organic matter-depleted, acidic Oxisols.
\end{abstract}

Additional keywords: aggregation, liming, no-tillage system, silicate application, soil structure.

Received 16 September 2016, accepted 12 April 2017, published online 15 June 2017

\section{Introduction}

The extensive use of soil for agriculture can result in widespread compaction and increased resistance to root penetration, in addition to reduced soil porosity and aggregate stability (Stone and Schlegel 2010; Tavares Filho et al. 2010; Castro et al. 2011). Changes in the soil physical characteristics as a result of intensive agriculture can greatly influence plant growth, and ultimately affect productivity and yields (Albuquerque et al. 2003). No-tillage is a soil management practice that helps to reduce soil disturbance, allowing for the accumulation of crop residues on the soil surface, and can increase the soil aggregate stability (Calonego and Rosolem 2008; Blanco-Canqui et al. 2010; Castro et al. 2011). Accumulation of post-harvest crop residues on the soil surface in no-tillage systems contributes to increased soil organic matter (SOM) concentrations and, as a consequence, helps the formation of more water-stable aggregates due to SOM's ability to promote aggregation of mineral soil particles (Wohlenberg et al. 2004; Wendling et al. 2005). Furthermore, Zonta et al. (2006) reported that roots also contribute to the process of aggregation and restoring soil structure by applying biophysical forces, both in the axial and radial directions, that bind mineral particles together as the roots pass through the porous spaces in the soil matrix. In addition, water absorption by the roots is responsible for drying the soil in the rhizosphere adjacent to the roots, which promotes increased cohesive forces between soil particles (Zonta et al. 2006).

Similar to disturbances by tillage operations, chemical changes in the soil caused by the application of certain materials for ameliorating soil acidity can negatively influence soil aggregate stability and other physical characteristics of the soil. Changes in soil $\mathrm{pH}$, solution ionic strength, and the types of ions in the soil solution can promote the dispersion or flocculation of soil colloids, consequently potentially interfering in the aggregation 
of soil particles (Seta and Karathanasis 1996). The dispersive action caused by certain soil amendments used for soil acidity correction can be intensified in no-tillage systems due to stratification and concentration of surface-applied materials within the top few centimetres of the soil profile (Costa et al. 2004). However, several field studies have reported that materials applied for ameliorating soil acidity can also indirectly and beneficially influence soil physical characteristics, as certain materials contribute to the production of aerial and radicular phytomass in plants, thus increasing the addition of organic matter and enhancing soil microbial activity (Albuquerque et al. 2003; Costa et al. 2004; Griève et al. 2005; Corrêa et al. 2009; Castro et al. 2011). Consequently, these factors help in the formation of soil aggregates.

Although crop rotation in no-tillage systems can enhance soil physical characteristics, particularly by improving plant root growth, and the application of large amounts of acid-neutralising materials can affect colloid aggregation and potentially reduce soil quality, little research has been conducted on soils with low SOM concentrations that are prone to acidity problems, such as Oxisols in northern South America. The climatic conditions in northern South America (i.e. hot temperatures and high annual rainfall) create an extreme soil weathering environment that causes rapid organic matter oxidation and accelerated leaching of weatherable minerals. Consequently, understanding the effects of acid-neutralising materials across various crop rotations in highly weathered Oxisols will provide valuable information that can help agricultural producers in northern South America to make well informed decisions about surficial application of materials for ameliorating soil acidity in no-tillage systems. Therefore, the objective of this study was to evaluate the effects of crop rotation and acid-neutralising material on near-surface soil physical properties under no-tillage in a Brazilian Oxisol. It was hypothesised that, since the effects of soil acidity correction on soil physical properties are indirect, crop rotation system will likely have a greater direct effect on soil physical properties than will acid-neutralising material and that more-intensive crop production systems, such as those with greater plant densities and greater crop residue production, will have greater effects than less-intensive production systems.

\section{Material and methods}

This field experiment was initiated in October 2006 at the Lageado Experimental Farm, in Botucatu, SP, Brazil $\left(48^{\circ} 23^{\prime} \mathrm{W}, 22^{\circ} 51^{\prime} \mathrm{S}\right.$; elevation of $765 \mathrm{~m}$ above sea level) on an Oxisol, classified as Red Ferrosol or Rhodic Ferralsol in the Australian Soil Classification System (Isbell 2016) with a sandy clay surface texture. The climate in the region is characterised as highland tropical (Rolim et al. 2007), with a relatively dry winter and wet, rainy summer. Monthly mean rainfall and temperature during the five years of the experiment (i.e. 2006-11) are presented in Fig. 1. The experimental area had been fallow since February 2000 and contained spontaneous vegetation. In July 2006, before experiment initiation, soil samples were collected from the top $0.2 \mathrm{~m}$ for chemical (van Raij et al. 2001) and physical analyses (Camargo et al. 2009) (Table 1).
A randomised complete block experimental design was established in a split-plot arrangement with eight replications. The whole-plot experimental unit was $5.4 \mathrm{~m}$ wide by $30 \mathrm{~m}$ long and occupied $162 \mathrm{~m}^{2}$, and the split-plot experimental unit was $5.4 \mathrm{~m}$ wide by $10 \mathrm{~m}$ long and occupied $54 \mathrm{~m}^{2}$. The whole-plot factor consisted of four production system variations of a soybean (Glycine max)-maize (Zea mays)-rice (Oryza sativa) crop rotation that differed in their off-season (i.e. FebruaryOctober) crop during 2007-11, either a forage crop, a second crop, a cover crop, or fallow (Table 2). The forage-crop production system used Congo signal grass (Urochloa ruziziensis) in each off-season. The second-crop production system used common oat (Avena sativa), common bean (Phaseolus vulgaris), castor bean (Ricinus communis), grain sorghum (Sorghum bicolor), and crambe (Crambe abyssinica) in each sequential off-season during 2007-11, respectively. The cover-crop production system used pearl millet (Pennisetum americanum), pigeon pea (Cajanus cajan), sunn hemp (Crotalaria juncea), pearl millet, and white lupin (Lupinus albus) in each sequential off-season during 2007-11, respectively. The crop-fallow production system had no crop grown during the off-season. All four production systems were managed under no-tillage soil management for the duration of this study.

The split-plot factor consisted of a lime or silicate application to ameliorate soil acidity plus an unamended control treatment. Lime and silicate rates were calculated to raise the soil base saturation to $70 \%$. In October 2006, before planting the first soybean crop in each of the four production systems, $3.8 \mathrm{Mg} \mathrm{ha}^{-1}$ of limestone $\left(360 \mathrm{~g} \mathrm{~kg}^{-1} \mathrm{CaO}\right.$ and $120 \mathrm{~g} \mathrm{~kg}^{-1} \mathrm{MgO}$; effective calcium carbonate equivalent (ECCE) of $90 \%$ ) and $4.1 \mathrm{Mg} \mathrm{ha}^{-1}$ of $\mathrm{Ca}-\mathrm{Mg}$ silicate $\left(340 \mathrm{~g} \mathrm{~kg}^{-1} \mathrm{CaO}, 100 \mathrm{~g} \mathrm{~kg}^{-1} \mathrm{MgO}\right.$, and $220 \mathrm{~g} \mathrm{~kg}^{-1} \mathrm{SiO}_{2}$; ECCE of $80 \%$ ) were surface-applied with a mechanical spreader to the corresponding plots. One row on each side of the split-plot experimental units and $1 \mathrm{~m}$ at both ends were considered borders. Details on the crops, planting dates, plant populations, row spacings, and crop harvest or management practices used are summarised in Table 3.

In 2011, after five complete cropping cycles in each of the four production systems, undisturbed soil samples were collected using a $5-\mathrm{cm}$ tall core cylinder with a $4.8-\mathrm{cm}$ internal diameter to determine soil bulk density (BD), total porosity, macroporosity, and microporosity. Trenches $\sim 0.4 \mathrm{~m}$ wide, $0.5 \mathrm{~m}$ long, and $0.6 \mathrm{~m}$ deep were opened. Samples were collected from the centre of the $0-0.1-, 0.1-0.2-$, and $0.2-0.4-\mathrm{m}$ depth intervals using a steel support to force the volumetric ring into the soil, manually with a slide hammer. Immediately after the soil sampling, the excess soil was removed and the volumetric rings received a plastic lid on each edge to prevent damage and they were carried to the laboratory and stored at $2^{\circ} \mathrm{C}$. Soil samples were then placed in plastic trays with water up to two-thirds of the cylinder height to saturate the core samples. To prevent soil loss, the bottom of the cylinder was wrapped with polyester fabric. Samples were weighed after $48 \mathrm{~h}$ of wetting to determine the saturated weight. Cylinders were then set on a tension table (Dane and Hopmans 2002) and subjected to a tension of $-6 \mathrm{kPa}$. Once the samples equilibrated to the imposed tension, which took 48-72 h, their wet masses were recorded. Samples were dried in a forced-air oven at $105^{\circ} \mathrm{C}$ for $48 \mathrm{~h}$ to determine the dry soil mass. BD was 

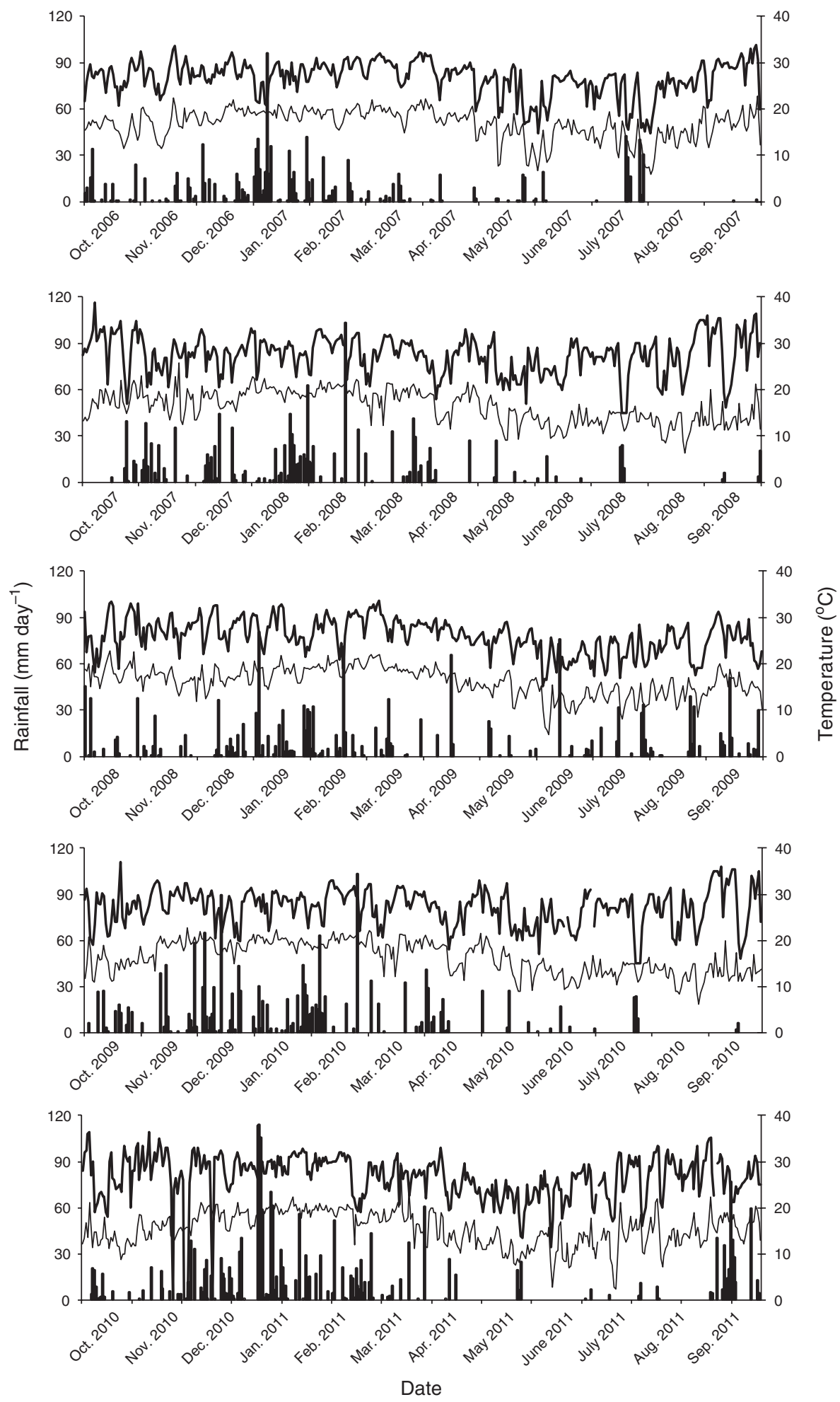

Fig. 1. Temperature and rainfall during the study period of October 2006 to September 2011.

calculated by dividing the dry soil mass by the volume of the soil cylinder collected. Considering that the water in the macropores was removed at $-6 \mathrm{kPa}$, the volume of micropores was determined from the water content measurement (Danielson and Sutherland 1986). Total soil porosity was assumed equivalent to the measured saturated volumetric water content. Macroporosity was obtained by calculating the difference between total porosity and microporosity. 
To evaluate soil aggregates, soil samples $0.05 \mathrm{~m}$ deep, $0.10 \mathrm{~m}$ long, and $0.15 \mathrm{~m}$ wide were collected at depths of $0-0.1-, 0.1-0.2-$, and 0.2 to $0.4-\mathrm{m}$ intervals from the same trenches used for the previous soil samples. These samples were collected using a pre-fabricated metal frame, which was manually inserted into the soil with a slide hammer and

Table 1. Summary of initial soil physical and chemical properties in the top 0.20-m layer of the Oxisol

\begin{tabular}{lr}
\hline Soil attribute & Value \\
\hline Physical attribute & \\
Sand $\left(\mathrm{g} \mathrm{kg}^{-1}\right)$ & 469 \\
Clay $\left(\mathrm{g} \mathrm{kg}^{-1}\right)$ & 440 \\
Silt $\left(\mathrm{g} \mathrm{kg}^{-1}\right)$ & 91 \\
Mean weight diameter $(\mathrm{mm})$ & 2.9 \\
Mean geometric diameter $(\mathrm{mm})$ & 2.8 \\
Aggregate Stability Index $(\%)$ & 99 \\
Soil bulk density $\left(\mathrm{Mg} \mathrm{m}^{-3}\right)$ & 1.40 \\
Total porosity $\left(\mathrm{m}^{3} \mathrm{~m}^{-3}\right)$ & 0.39 \\
Microporosity $\left(\mathrm{m}^{3} \mathrm{~m}^{-3}\right)$ & 0.32 \\
Macroporosity $\left(\mathrm{m}^{3} \mathrm{~m}^{-3}\right)$ & 0.07 \\
Chemical attribute & \\
$\mathrm{P}_{\text {resin }}\left(\mathrm{mg} \mathrm{dm}^{-3}\right)$ & 3.6 \\
Organic matter $\left(\mathrm{g} \mathrm{dm}^{-3}\right)$ & 18 \\
$\mathrm{pH}\left(\mathrm{CaCl}_{2}\right)$ & 4.2 \\
$\mathrm{~K}\left(\mathrm{mmol}_{\mathrm{c}} \mathrm{dm}^{-3}\right)$ & 0.7 \\
$\mathrm{Ca}\left(\mathrm{mmol}_{\mathrm{c}} \mathrm{dm}^{-3}\right)$ & 12 \\
$\mathrm{Mg}\left(\mathrm{mmol}_{\mathrm{c}} \mathrm{dm}^{-3}\right)$ & 6 \\
$\mathrm{H}^{+} \mathrm{Al}\left(\mathrm{mmol}_{\mathrm{c}} \mathrm{dm}^{-3}\right)$ & 54 \\
$\mathrm{Al}\left(\mathrm{mmol}_{\mathrm{c}} \mathrm{dm}^{-3}\right)$ & 4 \\
$\mathrm{Si}\left(\mathrm{mg} \mathrm{dm}^{-3}\right)$ & 6.2 \\
Base saturation $(\%)$ & 25 \\
\hline
\end{tabular}

removed with the aid of spatula. Samples were temporarily stored in plastic bags, and all fresh soil was manually passed through sieves with 8- and 4-mm openings. Approximately $0.1 \mathrm{~kg}$ of the soil that was retained on the 4-mm sieve was air-dried and used for subsequent analysis for aggregate stability.

Table 2. Summary of specific crops grown during the main cropgrowing season and off-season for 2006-11 for each of four production systems

\begin{tabular}{|c|c|c|c|c|}
\hline Year/Season & $\begin{array}{l}\text { System I } \\
\text { (forage crop) }\end{array}$ & $\begin{array}{l}\text { System II } \\
\text { (second crop) }\end{array}$ & $\begin{array}{l}\text { System III } \\
\text { (cover crop) }\end{array}$ & $\begin{array}{l}\text { System IV } \\
\text { (crop-fallow) }\end{array}$ \\
\hline \multicolumn{5}{|l|}{2006} \\
\hline Off-season & - & - & - & - \\
\hline Crop season & Soybean & Soybean & Soybean & Soybean \\
\hline \multicolumn{5}{|l|}{2007} \\
\hline Off-season & Signal grass & Common oats & Pearl millet & Fallow \\
\hline Crop season & Maize & Maize & Maize & Maize \\
\hline \multicolumn{5}{|l|}{2008} \\
\hline Off-season & Signal grass & Common bean & Pigeon pea & Fallow \\
\hline Crop season & Upland rice & Upland rice & Upland rice & Upland rice \\
\hline \multicolumn{5}{|l|}{2009} \\
\hline Off-season & Signal grass & Castor bean & Sunn hemp & Fallow \\
\hline Crop season & Soybean & Soybean & Soybean & Soybean \\
\hline \multicolumn{5}{|l|}{2010} \\
\hline Off-season & Signal grass & Grain sorghum & Pearl millet & Fallow \\
\hline Crop season & Maize & Maize & Maize & Maize \\
\hline \multicolumn{5}{|l|}{2011} \\
\hline Off-season & Signal grass & Crambe & White lupin & Fallow \\
\hline Crop season & - & - & - & - \\
\hline
\end{tabular}

Table 3. Summary of relevant agronomic information (i.e. cultivar, sowing date, row spacing, sowing density, and date of harvest or management) used in the crop rotations for 2006-11

\begin{tabular}{|c|c|c|c|c|c|}
\hline Crop & Cultivar & $\begin{array}{l}\text { Sowing date } \\
\text { (dd/mm/yyyy) }\end{array}$ & Row spacing (m) & Sowing density & $\begin{array}{c}\text { Harvest/management } \\
\text { date }(\mathrm{dd} / \mathrm{mm} / \text { yyyy })\end{array}$ \\
\hline \multirow[t]{2}{*}{ Soybean } & \multirow[t]{2}{*}{ Embrapa 48 CD 202} & $29 / 11 / 2006$ & \multirow[t]{2}{*}{0.45} & 22 plants $\mathrm{m}^{-1}$ & 03/04/2007 \\
\hline & & $30 / 11 / 2009$ & & 18 plants $\mathrm{m}^{-1}$ & $29 / 03 / 2010$ \\
\hline \multirow[t]{3}{*}{ Pearl millet } & \multirow[t]{3}{*}{ BRS 1501 ADR 500} & $10 / 04 / 2007$ & \multirow[t]{3}{*}{0.45} & $25 \mathrm{~kg} \mathrm{ha}^{-1}$ & $30 / 05 / 2007$ and \\
\hline & & $30 / 03 / 2010$ & & $15 \mathrm{~kg} \mathrm{ha}^{-1}$ & $04 / 07 / 2007$ \\
\hline & & & & & $\begin{array}{l}24 / 05 / 2010 \text { and } \\
03 / 07 / 2010\end{array}$ \\
\hline Common oat & IAC 7 & $10 / 04 / 2007$ & 0.45 & 133 seeds $\mathrm{m}^{-2}$ & $30 / 07 / 2007$ \\
\hline \multirow[t]{5}{*}{ Signal grass } & \multirow[t]{5}{*}{ Urochloa ruziziensis } & $10 / 04 / 2007$ & 0.45 & $2.5 \mathrm{~kg} \mathrm{ha}^{-1}$ & $01 / 12 / 2007$ \\
\hline & & 05/04/2008 & & & $25 / 10 / 2008$ \\
\hline & & $10 / 04 / 2009$ & & & $28 / 11 / 2009$ \\
\hline & & $30 / 03 / 2010$ & & & $10 / 11 / 2010$ \\
\hline & & $22 / 04 / 2011$ & \multirow{3}{*}{0.45} & \multirow{3}{*}{3 seeds $\mathrm{m}^{-1}$} & 01/11/2011 \\
\hline \multirow[t]{2}{*}{ Maize } & Hybrid 2B570 & $02 / 12 / 2007$ & & & $01 / 04 / 2008$ \\
\hline & Hybrid 2B433 & $18 / 11 / 2010$ & & & $21 / 03 / 2011$ \\
\hline Common bean & Pérola & 05/04/2008 & 0.45 & 18 seeds $\mathrm{m}^{-1}$ & $29 / 06 / 2008$ \\
\hline Pigeon pea & IAPAR 43 & $05 / 04 / 2008$ & 0.45 & 20 seeds $\mathrm{m}^{-1}$ & $01 / 07 / 2008$ \\
\hline Upland rice & IAC 202 & $29 / 10 / 2008$ & 0.45 & 200 seeds $\mathrm{m}^{-2}$ & 03/04/2009 \\
\hline Castor bean & IAC 2028 & $10 / 04 / 2009$ & 0.45 & 3 seeds $\mathrm{m}^{-1}$ & $01 / 10 / 2009$ \\
\hline Sunn hemp & IAC-KR1 & $10 / 04 / 2009$ & 0.45 & $25 \mathrm{~kg} \mathrm{ha}^{-1}$ & $19 / 07 / 2009$ \\
\hline Grain sorghum & Hybrid AG-1040 & $30 / 03 / 2010$ & 0.45 & $10 \mathrm{~kg} \mathrm{ha}^{-1}$ & $29 / 07 / 2010$ \\
\hline Crambe & FMS Brilhate & $22 / 04 / 2011$ & 0.34 & $15 \mathrm{~kg} \mathrm{ha}^{-1}$ & $08 / 08 / 2011$ \\
\hline White lupin & Comum & $22 / 04 / 2011$ & 0.34 & $50 \mathrm{~kg} \mathrm{ha}^{-1}$ & $08 / 08 / 2011$ \\
\hline
\end{tabular}


Soil aggregate stability was determined based on procedures described in Kemper and Chepil (1965). Two 25-g sub-samples of soil retained on the 4-mm sieve and air-dried were weighed: one was used for moisture determination by gravimetric method (Gardner 1986) and the other was wet-sieved. The sub-samples for sieving were lightly pre-wetted with a sprinkler and left at room temperature for $10 \mathrm{~min}$. Sub-samples were then transferred to the top of a nest of sieves with 2-, 1-, 0.5-, 0.25-, and 0.105$\mathrm{mm}$ diameter openings attached to a vertical oscillation unit (Yoder 1936). Sieving was performed with vertical oscillation (30 oscillations per minute) of the nest of sieves immersed in water for $15 \mathrm{~min}$. The portion of soil retained on each sieve after $15 \mathrm{~min}$ was gently washed into aluminium pots and dried at $105^{\circ} \mathrm{C}$ for $24 \mathrm{~h}$. The percentage of aggregates retained on the $2-\mathrm{mm}$ sieve (i.e. aggregates $>2 \mathrm{~mm}$ in diameter), the mean weight diameter (MWD), and the mean geometric diameter (MGD) were determined. Similar to that described in Castro Filho et al. (2002), an aggregate stability index (ASI) was calculated. Eqns 1-3 below were used to calculate MWD, MGD, and ASI, respectively:

$$
\begin{gathered}
\mathrm{MWD}=\frac{\sum_{i=1}^{n} \tilde{x}_{i} w_{i}}{\sum_{i=1}^{n} w_{i}} \\
\mathrm{MGD}=\exp \left[\frac{\sum_{i=1}^{n} w_{i} \ln \tilde{x}_{i}}{\sum_{i=1}^{n} w_{i}}\right] \\
\mathrm{ASI}=\frac{w_{\mathrm{s}}-w_{<0.25}}{w_{\mathrm{s}}} \times 100
\end{gathered}
$$

where MWD and MGD are in mm, ASI is in $\%, \tilde{x}_{i}$ is the mean diameter of each size fraction $(\mathrm{mm}), w_{i}$ is the total sample mass occurring in the corresponding size fraction $(\mathrm{g}), w_{\mathrm{s}}$ is the original dry soil mass $(\mathrm{g})$, and $w_{<0.25}$ is the mass of aggregates $<0.25 \mathrm{~mm}$ in size $(\mathrm{g})$.
Soil mechanical resistance to penetration was determined using a hydraulic-driven electronic penetrometer with metal rod having a conical tip of $30^{\circ}$ solid angle (Santos and Lanças 1999). Penetration resistance was performed twice per experimental unit up to a depth of $0.4 \mathrm{~m}$. To reduce variations in soil moisture among treatments and soil depths, measurements were performed three days after a thoroughly soaking rainfall, after which soil moisture in the top $0.4 \mathrm{~m}$ was assumed uniform within the entire study area. In addition to assuming uniform soil moisture conditions after the rainfall event, soil was also collected at depths of $0.05,0.15$, and $0.3 \mathrm{~m}$ for determination of gravimetric soil moisture (Camargo et al. 2009).

Analysis of variance was used to evaluate the effects of production system (whole-plot factor), acid-neutralising soil amendment (split-plot factor), and their interaction on soil physical properties. Treatment means were compared using the least significant difference (LSD) paired test at $\alpha=0.05$. All statistical analyses were performed using the SAS/STAT software package (version 9.2, SAS Institute Inc., Cary, NC, USA).

\section{Results and discussion \\ Production system effects}

After five complete cropping cycles, most soil physical properties evaluated in this study were affected by production system $(P<0.05)$ in the $0-0.1$ - (Table 4) and $0.1-0.2-\mathrm{m}$ (Table 5) depth intervals. BD in the $0-0.1-\mathrm{m}$ interval was $5 \%$ lower $(P=0.037)$ in the forage crop than in all other production systems, which did not differ and averaged $1.27 \mathrm{Mg} \mathrm{m}^{-3}$ (Table 4). Consequently, macroporosity in the $0-0.1-\mathrm{m}$ interval was at least $3 \%$ greater $(P=0.012)$ in the forage crop than in all other production systems (Table 4 ). The crop-fallow production system had the lowest, and the second-crop and cover-crop production systems (which did not differ) had an intermediate macroporosity in the $0-0.1-\mathrm{m}$ interval (Table 4 ). Similar to

Table 4. Summary of the effects of production system, soil amendment, and their interaction on soil bulk density (BD), total porosity (TP), microporosity (Mic), macroporosity (Mac), mean weight diameter (MWD), mean geometric diameter (MGD), and aggregate stability index (ASI) in the 0-0.1-m depth interval after five complete cropping cycles under

\begin{tabular}{|c|c|c|c|c|c|c|c|}
\hline $\begin{array}{l}\text { Source of variation/ } \\
\text { treatment }\end{array}$ & $\begin{array}{c}\mathrm{BD} \\
\left(\mathrm{Mg} \mathrm{m}^{-3}\right)\end{array}$ & $\begin{array}{c}\mathrm{TP} \\
\left(\mathrm{cm}^{3} \mathrm{~cm}^{-3}\right)\end{array}$ & $\begin{array}{c}\text { Mic } \\
\left(\mathrm{cm}^{3} \mathrm{~cm}^{-3}\right)\end{array}$ & $\begin{array}{c}\mathrm{Mac} \\
\left(\mathrm{cm}^{3} \mathrm{~cm}^{-3}\right)\end{array}$ & $\begin{array}{l}\text { MWD } \\
(\mathrm{mm})\end{array}$ & $\begin{array}{l}\text { MGD } \\
(\mathrm{mm})\end{array}$ & ASI $(\%)$ \\
\hline Crop-fallow & $1.28 \mathrm{~b}$ & $0.49 \mathrm{a}$ & $0.40 \mathrm{a}$ & $0.09 \mathrm{c}$ & $3.77 \mathrm{a}$ & $3.18 \mathrm{a}$ & $87.9 \mathrm{c}$ \\
\hline Second crop & $1.27 \mathrm{~b}$ & $0.55 \mathrm{a}$ & $0.44 \mathrm{a}$ & $0.11 b$ & $3.79 \mathrm{a}$ & $3.37 \mathrm{a}$ & $91.9 \mathrm{~b}$ \\
\hline Cover crop & $1.26 \mathrm{~b}$ & $0.54 \mathrm{a}$ & $0.43 \mathrm{a}$ & $0.11 b$ & $3.69 \mathrm{a}$ & $2.99 \mathrm{a}$ & $91.2 b$ \\
\hline \multicolumn{8}{|l|}{ Soil amendment } \\
\hline Control & $1.28 \mathrm{~b}$ & $0.53 \mathrm{a}$ & $0.43 \mathrm{a}$ & $0.10 \mathrm{~b}$ & $3.68 \mathrm{a}$ & $3.20 \mathrm{a}$ & $91.2 \mathrm{a}$ \\
\hline Silicate & $1.23 \mathrm{a}$ & $0.55 \mathrm{a}$ & $0.43 \mathrm{a}$ & $0.12 \mathrm{a}$ & $3.79 \mathrm{a}$ & $3.17 \mathrm{a}$ & $92.2 \mathrm{a}$ \\
\hline Limestone & $1.22 \mathrm{a}$ & $0.54 \mathrm{a}$ & $0.42 \mathrm{a}$ & $0.12 \mathrm{a}$ & $3.81 \mathrm{a}$ & $3.22 \mathrm{a}$ & $90.7 \mathrm{a}$ \\
\hline Overall mean & 1.26 & 0.54 & 0.43 & 0.11 & 3.77 & 3.19 & 91.3 \\
\hline Soil amendment (SA) & 0.022 & 0.450 & 0.339 & 0.003 & 0.112 & 0.194 & 0.064 \\
\hline $\mathrm{PS} \times \mathrm{SA}$ & 0.091 & 0.288 & 0.082 & 0.087 & 0.101 & 0.123 & 0.075 \\
\hline
\end{tabular}
no-tillage in a Brazilian Oxisol

Values followed by the same letter in a treatment within a column do not differ $(P>0.05)$ 
Table 5. Summary of the effects of production system, soil amendment, and their interaction on soil bulk density (BD), total porosity (TP), microporosity (Mic), macroporosity (Mac), mean weight diameter (MWD), mean geometric diameter (MGD), and aggregate stability index (ASI) in the 0.1-0.2-m depth interval after five complete cropping cycles under no-tillage in a Brazilian Oxisol

Values followed by the same letter in a treatment within a column do not differ $(P>0.05)$

\begin{tabular}{|c|c|c|c|c|c|c|c|}
\hline $\begin{array}{l}\text { Source of variation/ } \\
\text { treatment }\end{array}$ & $\begin{array}{c}\mathrm{BD} \\
\left(\mathrm{Mg} \mathrm{m}^{-3}\right)\end{array}$ & $\begin{array}{c}\mathrm{TP} \\
\left(\mathrm{cm}^{3} \mathrm{~cm}^{-3}\right)\end{array}$ & $\begin{array}{c}\text { Mic } \\
\left(\mathrm{cm}^{3} \mathrm{~cm}^{-3}\right)\end{array}$ & $\begin{array}{c}\mathrm{Mac} \\
\left(\mathrm{cm}^{3} \mathrm{~cm}^{-3}\right)\end{array}$ & $\begin{array}{l}\text { MWD } \\
(\mathrm{mm})\end{array}$ & $\begin{array}{l}\text { MGD } \\
(\mathrm{mm})\end{array}$ & $\begin{array}{l}\text { ASI } \\
(\%)\end{array}$ \\
\hline \multicolumn{8}{|l|}{ Production system } \\
\hline Crop-fallow & $1.31 \mathrm{a}$ & $0.49 \mathrm{a}$ & $0.39 \mathrm{a}$ & $0.10 \mathrm{~b}$ & $3.30 \mathrm{~b}$ & $2.91 \mathrm{~b}$ & $90.3 \mathrm{a}$ \\
\hline Second crop & $1.31 \mathrm{a}$ & $0.50 \mathrm{a}$ & $0.38 \mathrm{a}$ & $0.11 \mathrm{ab}$ & $3.36 \mathrm{~b}$ & $2.89 \mathrm{~b}$ & $90.1 \mathrm{a}$ \\
\hline Cover crop & $1.32 \mathrm{a}$ & $0.47 \mathrm{a}$ & $0.36 \mathrm{a}$ & $0.11 \mathrm{ab}$ & $3.31 \mathrm{~b}$ & $2.90 \mathrm{~b}$ & $90.6 a$ \\
\hline Forage crop & $1.31 \mathrm{a}$ & $0.48 \mathrm{a}$ & $0.37 \mathrm{a}$ & $0.12 \mathrm{a}$ & $3.69 \mathrm{a}$ & $3.22 \mathrm{a}$ & $91.0 \mathrm{a}$ \\
\hline \multicolumn{8}{|l|}{ Soil amendment } \\
\hline Control & $1.32 \mathrm{a}$ & $0.49 \mathrm{a}$ & $0.39 \mathrm{a}$ & $0.10 \mathrm{~b}$ & $3.41 \mathrm{a}$ & $2.98 \mathrm{a}$ & $90.2 \mathrm{a}$ \\
\hline Silicate & $1.32 \mathrm{a}$ & $0.48 \mathrm{a}$ & $0.37 \mathrm{a}$ & $0.11 \mathrm{a}$ & $3.41 \mathrm{a}$ & $2.97 \mathrm{a}$ & $90.4 \mathrm{a}$ \\
\hline Limestone & $1.31 \mathrm{a}$ & $0.49 \mathrm{a}$ & $0.37 \mathrm{a}$ & $0.12 \mathrm{a}$ & $3.42 \mathrm{a}$ & $2.99 \mathrm{a}$ & $90.9 \mathrm{a}$ \\
\hline $\begin{array}{l}\text { Overall mean } \\
\mathrm{P} \text { values }\end{array}$ & 1.31 & 0.49 & 0.38 & 0.11 & 3.42 & 2.98 & 90.5 \\
\hline Production system (PS) & 0.254 & 0.182 & 0.163 & 0.026 & 0.031 & 0.037 & 0.172 \\
\hline Soil amendment (SA) & 0.081 & 0.125 & 0.182 & 0.039 & 0.092 & 0.149 & 0.119 \\
\hline $\mathrm{PS} \times \mathrm{SA}$ & 0.410 & 0.261 & 0.257 & 0.097 & 0.091 & 0.184 & 0.315 \\
\hline
\end{tabular}

macroporosity, ASI was at least 3\% greatest in the forage crop, intermediate in the second crop and cover crop (which did not differ) and lowest in the crop-fallow production system in the $0-0.1-\mathrm{m}$ interval $(P=0.020$; Table 4$)$. Total soil porosity (average $0.54 \mathrm{~cm}^{3} \mathrm{~cm}^{-3}$ ), microporosity (average $0.43 \mathrm{~cm}^{3} \mathrm{~cm}^{-3}$ ), MWD (average $3.76 \mathrm{~mm}$ ), and MGD (average $3.19 \mathrm{~mm}$ ) (Table 4) were unaffected by production system in the $0-0.1-\mathrm{m}$ interval across production systems and soil amendments.

Similar to the top $0.1 \mathrm{~m}$, after five complete cropping cycles, soil macroporosity differed $(P=0.026)$ among production systems in the $0.1-0.2-\mathrm{m}$ interval (Table 5). However, in contrast to the top $0.1 \mathrm{~m}, \mathrm{MWD}$ and MGD also differed $(P<0.05)$ among production systems in the $0.1-0.2-\mathrm{m}$ interval (Table 5). Macroporosity in the $0.1-0.2-\mathrm{m}$ interval was $2 \%$ greater in the forage crop than in the crop-fallow production system (Table 5). Both MWD and MGD were 11\% greater in the forage crop than in all other production systems (which did not differ) and averaged 3.32 and $2.90 \mathrm{~mm}$, respectively (Table 5). In contrast to the top $0.1 \mathrm{~m}, \mathrm{BD}$ and ASI were unaffected and, similarly to the top $0.1 \mathrm{~m}$, total soil porosity and microporosity were also unaffected by production system in the $0.1-0.2-\mathrm{m}$ interval and averaged $1.31 \mathrm{Mg} \mathrm{m}^{-3}, 90.5 \%$, $0.48 \mathrm{~cm}^{3} \mathrm{~cm}^{-3}$, and $0.37 \mathrm{~cm}^{3} \mathrm{~cm}^{-3}$, respectively, across production systems and soil amendments (Table 5).

Based on literature reports, the ideal soil for plant cultivation should possess macroporosity of $0.10-0.16 \mathrm{~cm}^{3} \mathrm{~cm}^{-3}$, microporosity up to $0.33 \mathrm{~cm}^{3} \mathrm{~cm}^{-3}$, and total soil porosity of $\sim 0.50 \mathrm{~cm}^{3} \mathrm{~cm}^{-3}$ (Baver et al. 1972; Kiehl 1979). However, a consistent critical BD has not yet been established. Camargo and Alleoni (1997) considered $1.6 \mathrm{Mg} \mathrm{m}^{-3}$ as the critical value for sandy to clay soils. In contrast, De Maria et al. (1999) reported restrictions on root system growth with BD greater than $1.2 \mathrm{Mg} \mathrm{m}^{-3}$ in Oxisols, which indicates some degree of negative effects on plants due to soil compaction. Thus, based on the data presented in the literature, it is likely that the BD and porosity measured in this field study were at least adequate for plant cultivation.

In contrast to the top $0.2 \mathrm{~m}$, no soil physical properties evaluated in this study were affected by production system in the 0.2-0.4-m interval (Table 6). BD, total porosity, microporosity, macroporosity, MWD, MGD, and ASI averaged $1.26 \mathrm{Mg} \mathrm{m}^{-3}, \quad 0.43 \mathrm{~cm}^{3} \mathrm{~cm}^{-3}, \quad 0.38 \mathrm{~cm}^{3} \mathrm{~cm}^{-3}, \quad 0.05 \mathrm{~cm}^{3} \mathrm{~cm}^{-3}$, $2.99 \mathrm{~mm}, 2.65 \mathrm{~mm}$, and $95.6 \%$, respectively, across production systems and soil amendments in the 0.2-0.4-m interval (Table 6). After five complete cropping cycles, penetration resistance increased with depth in the soil profile across all production systems, with values ranging from 1.70 MPa near the surface to $3.1 \mathrm{MPa}$ at $0.3 \mathrm{~m}$ depth (Fig. $2 a$ ). The maintenance of the crop-fallow production system for five consecutive years resulted in greater penetration resistance in the $0.1-0.2-\mathrm{m}$ depth interval compared with the other three production systems (Fig. 2a). This result was likely due to a combination of poorer characteristics related to soil structure in the $0.1-0.2-\mathrm{m}$ interval promoted by the crop-fallow system (Tables 4 and 5) and by the slight decrease in soil moisture in this layer relative to the surface at the time penetration resistance was measured (Fig. 2b). However, Cunha et al. (2007) also measured lower penetration resistance in the top $0.1 \mathrm{~m}$ in treatments including crop rotation under no-tillage with off-season signal grass (Brachiaria spp.) grown, where results were attributed to increased SOM content and soil aggregation. In addition, ignoring potential differences in soil moisture, Calonego et al. (2011) demonstrated that the management system that included a combination of corn and Brachiaria had lower penetration resistance in the 0.2-0.4-m interval compared with monoculture corn.

The effects of production system measured in this study may be related to the increase in root system growth caused by the changes in soil chemical characteristics due to the application of materials for soil acidity correction, thus enabling better 
Table 6. Summary of the effects of production system, soil amendment, and their interaction on soil bulk density (BD), total porosity (TP), microporosity (Mic), macroporosity (Mac), mean weight diameter (MWD), mean geometric diameter (MGD), and aggregate stability index (ASI) in the 0.2-0.4-m depth interval after five complete cropping cycles under no-tillage in a Brazilian Oxisol

Values followed by the same letter in a treatment within a column do not differ $(P>0.05)$

\begin{tabular}{|c|c|c|c|c|c|c|c|}
\hline $\begin{array}{l}\text { Source of variation/ } \\
\text { treatment }\end{array}$ & $\begin{array}{c}\mathrm{BD} \\
\left(\mathrm{Mg} \mathrm{m}^{-3}\right)\end{array}$ & $\begin{array}{c}\mathrm{TP} \\
\left(\mathrm{cm}^{3} \mathrm{~cm}^{-3}\right)\end{array}$ & $\begin{array}{c}\text { Mic } \\
\left(\mathrm{cm}^{3} \mathrm{~cm}^{-3}\right)\end{array}$ & $\begin{array}{c}\mathrm{Mac} \\
\left(\mathrm{cm}^{3} \mathrm{~cm}^{-3}\right)\end{array}$ & $\begin{array}{l}\text { MWD } \\
(\mathrm{mm})\end{array}$ & $\begin{array}{l}\text { MGD } \\
(\mathrm{mm})\end{array}$ & $\begin{array}{l}\text { ASI } \\
(\%)\end{array}$ \\
\hline \multicolumn{8}{|l|}{ Production system } \\
\hline Crop-fallow & $1.25 \mathrm{a}$ & $0.42 \mathrm{a}$ & $0.37 \mathrm{a}$ & $0.05 \mathrm{a}$ & $3.01 \mathrm{a}$ & $2.65 \mathrm{a}$ & $96.7 \mathrm{a}$ \\
\hline Second crop & $1.26 \mathrm{a}$ & $0.43 \mathrm{a}$ & $0.38 \mathrm{a}$ & $0.05 \mathrm{a}$ & $3.05 \mathrm{a}$ & $2.65 \mathrm{a}$ & $94.5 \mathrm{a}$ \\
\hline Cover crop & $1.26 \mathrm{a}$ & $0.43 a$ & $0.38 \mathrm{a}$ & $0.05 \mathrm{a}$ & $2.87 \mathrm{a}$ & $2.66 \mathrm{a}$ & $94.7 \mathrm{a}$ \\
\hline Forage crop & $1.27 \mathrm{a}$ & $0.43 \mathrm{a}$ & $0.38 \mathrm{a}$ & $0.05 \mathrm{a}$ & $3.04 \mathrm{a}$ & $2.63 \mathrm{a}$ & $96.6 \mathrm{a}$ \\
\hline \multicolumn{8}{|l|}{ Soil amendment } \\
\hline Control & $1.24 \mathrm{a}$ & $0.43 \mathrm{a}$ & $0.38 \mathrm{a}$ & $0.05 \mathrm{a}$ & $2.94 \mathrm{a}$ & $2.62 \mathrm{a}$ & $96.5 \mathrm{a}$ \\
\hline Silicate & $1.27 \mathrm{a}$ & $0.42 \mathrm{a}$ & $0.37 \mathrm{a}$ & $0.05 \mathrm{a}$ & $3.04 \mathrm{a}$ & $2.69 \mathrm{a}$ & $96.1 \mathrm{a}$ \\
\hline Limestone & $1.27 \mathrm{a}$ & $0.43 \mathrm{a}$ & $0.38 \mathrm{a}$ & $0.05 \mathrm{a}$ & $2.99 \mathrm{a}$ & $2.63 \mathrm{a}$ & $94.3 \mathrm{a}$ \\
\hline $\begin{array}{l}\text { Overall mean } \\
\mathrm{P} \text { values }\end{array}$ & 1.26 & 0.43 & 0.38 & 0.05 & 2.99 & 2.65 & 95.6 \\
\hline Production system (PS) & 0.721 & 0.779 & 0.519 & 0.574 & 0.085 & 0.638 & 0.092 \\
\hline Soil amendment (SA) & 0.236 & 0.404 & 0.381 & 0.622 & 0.513 & 0.499 & 0.328 \\
\hline $\mathrm{PS} \times \mathrm{SA}$ & 0.097 & 0.401 & 0.089 & 0.626 & 0.308 & 0.325 & 0.164 \\
\hline
\end{tabular}

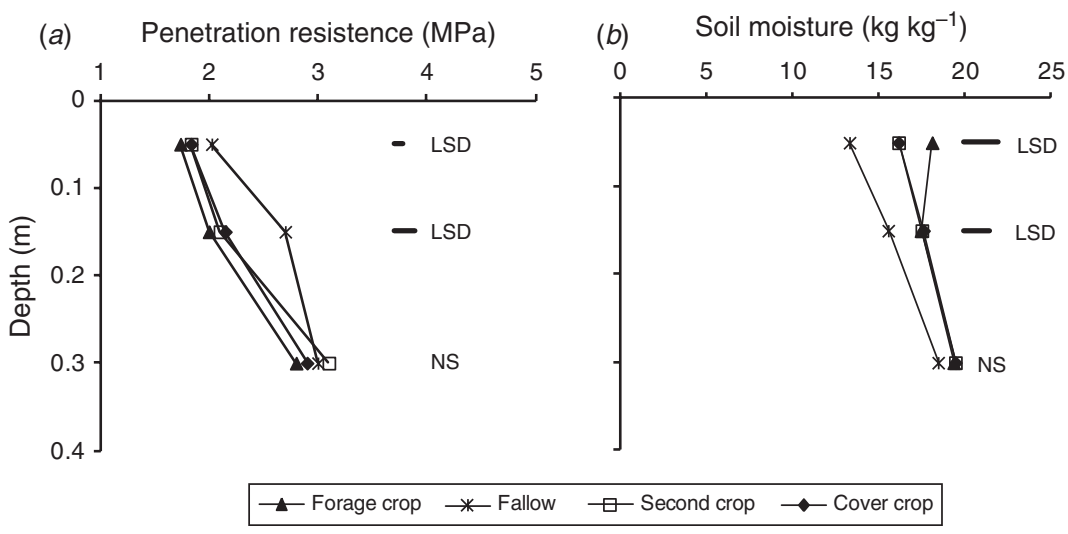

Fig. 2. Penetration resistance $(a)$ and soil moisture $(b)$ as a function of depth as affected by production system in a Brazilian Oxisol under no-tillage in 2011 after five complete cropping cycles. Horizontal bars indicate the least significant difference (LSD). NS, non-significant.

development. In addition, the cultivation of a second crop in the same year would increase root density in the plough layer and rhizosphere, which would, in turn, likely increase some aspects of soil porosity - total, macroporosity, or microporosity - due to channels left by the dead and decaying roots in the soil (Silva and Rosolem 2001).

Bayer and Mielniczuk (2008) reported that the root system of tropical forage plants can promote soil aggregation. This benefit can justify the intermediate effect of production systems that include the growth of second crops and forage plants during the off-season. In addition to affecting the root density, off-season crops provide greater accumulation of organic residues on the soil surface, particularly in the notillage soil management system used in this study. Huang et al. (2010) observed a positive influence of greater quantities of organic residues on soil aggregation provided by forage plants.
Several researchers have reported on the relationship between plants with fasciculated root systems and soil structure (Silva and Mielniczuk 1997; Calonego and Rosolem 2008), and have identified benefits for root system and overall growth of soybean (Calonego and Rosolem 2010). Salton et al. (2008) showed that grass contributed to greater soil aggregation due to their fibrous and dense root systems. According to Bayer and Mielniczuk (2008), management systems that enhance root growth and distribution within the soil profile can help to improve aggregate stability by increasing the concentration of aggregate-promoting substances (i.e. materials with cementation and unifying functions, such as organic matter and root exudates). Soil aggregation is also promoted as roots penetrate and expand through pores forcing mineral particles closer together and cohesion strength between soil particles increases near the root surface as the rhizosphere soil dries out from water absorption (Zonta et al. 2006). 
One main difference in soil physical characteristics in the surface layers among various land-use and production systems is due to the presence of plant residues and to the greater concentration of roots near the soil surface (Garcia and Rosolem 2010). According to Cunha et al. (2007), the effect of management systems on aggregate stability is mostly observed in the upper layers of the soil, near the soil surface, where greater differences in SOM concentration between management systems are commonly observed. However, although the results of this study reflect five consecutive years of treatment application, this may not be long enough to change many other physical properties of the soil beyond those that were measured and changed in this study. Therefore, considering the absence of treatment responses in the $0.2-0.4-\mathrm{m}$ interval in this study (Table 6), it is expected that an intermediate- to a longterm period of consistent management, beyond five years, is required to affect changes in soil physical properties deeper in the soil profile (Blanco-Canqui et al. 2010).

\section{Soil amendment effects}

Similar to production system, $\mathrm{BD}(P=0.022)$ and macroporosity $(P=0.003)$ differed among soil amendments, but total porosity, microporosity, MWD, and MGD were unaffected by soil amendments after five complete cropping cycles in the $0-0.1-\mathrm{m}$ interval (Table 4). However, in contrast to production system, ASI was also unaffected by soil amendments in the $0-0.1-\mathrm{m}$ depth interval (Table 4). BD was 5\% lower under the lime- and silicate-amended soil, which did not differ, than under the unamended control in the $0-0.1-\mathrm{m}$ depth interval (Table 4). Similar to BD, macroporosity was $2 \%$ greater under the limeand silicate-amended soil, which did not differ, compared with the unamended control in the 0-0.1-m interval (Table 4). Total porosity, microporosity, MWD, MGD, and ASI averaged $0.54 \mathrm{~cm}^{3} \mathrm{~cm}^{-3}, 0.43 \mathrm{~cm}^{3} \mathrm{~cm}^{-3}, 3.76 \mathrm{~mm}, 3.20 \mathrm{~mm}$, and $91.4 \%$, respectively, across soil amendments in the $0-0.1-\mathrm{m}$ interval (Table 4).

Similar to that in the $0-0.1-\mathrm{m}$ interval, soil macroporosity differed $(P=0.039)$ among soil amendments in the $0.1-0.2-\mathrm{m}$ interval after five complete cropping cycles (Table 5). However, in contrast to production system, liming agent did not affect any other soil physical property in the $0.1-0.2-\mathrm{m}$ interval (Table 5). Macroporosity was at least $1 \%$ greater under the lime- and silicate-amended soil, which did not differ, compared with the unamended control in the 0.1-0.2-m interval (Table 5). $\mathrm{BD}$, total porosity, microporosity, MWD, MGD, and ASI averaged $1.32 \mathrm{Mg} \mathrm{m}^{-3}, 0.49 \mathrm{~cm}^{3} \mathrm{~cm}^{-3}, 0.37 \mathrm{~cm}^{3} \mathrm{~cm}^{-3}, 3.41 \mathrm{~mm}$, $2.98 \mathrm{~mm}$, and $90.5 \%$, respectively, across soil amendments in the $0.1-0.2-\mathrm{m}$ interval (Table 5).

In contrast to the top $0.2 \mathrm{~m}$, but similar to that for production system, none of the measured soil physical properties were affected by soil amendments in the $0.2-0.4-\mathrm{m}$ interval (Table 6). Similarly, application of materials for soil acidity correction did not influence penetration resistance or soil moisture at any depth in the top $0.4 \mathrm{~m}$.

Results showed that production systems with a greater capacity to produce biomass during the autumn-winter planting season, such as Congo signal grass (Castro et al. 2011), presented many similar results compared with the treatments that received the application of materials for soil acidity correction. Both acid-neutralising soil amendments helped to reduce $\mathrm{BD}$ in the $0-0.1-\mathrm{m}$ depth and increase macroporosity in the $0-0.1-$ and $0.1-0.2-\mathrm{m}$ depths compared with the unamended control. This suggests that the addition of polyvalent cations in the soil amendments contributed to somewhat greater flocculation and aggregation.

Some have reported that the concentrated application of materials for soil acidity correction on the soil surface, such as that which would occur under no-tillage management where the acid-neutralising material does not get incorporated, would lead to clay dispersion (Castro et al. 2011), thus resulting in a process of physical degradation of the soil. However, results of this study showed that five consecutive years of addition of materials for soil acidity correction did not reduce the diameter or the stability of soil aggregates relative to an unamended control in the top $0.4 \mathrm{~m}$ (Tables 4-6).

The absence of a negative effect of the application of acidneutralising materials on soil aggregation has been observed previously. Costa et al. (2004) reported that the accumulation of soil carbon and the increase in soil microbial activity in the root system of crops, as a result of the application of acidneutralising materials, contribute to maintaining aggregate stability, while off-setting the potential dispersive effect of certain acid-neutralising materials. The benefits provided by acid-neutralising soil amendments on the production of dry mass during the five complete cropping cycles could have minimised any potential undesirable effects of clay dispersion. Similarly, Bortoluzzi et al. (2010) reported soil physical property improvement resulted from the application of acidneutralising materials.

Furthermore, although increased $\mathrm{BD}$ and decreased macroporosity are often assumed to be common negative effects of no-tillage crop production, particularly in clay soils, results of this study showed that these negative effects are not universal because the forage-crop production system had the lowest BD and greater macroporosity in the top $0.2 \mathrm{~m}$ after five complete cropping cycles compared with the other production systems evaluated.

\section{Implications}

Soil management practices that enhance macroporosity for improved soil aeration should be implemented in areas with a low proportion of macropores, such as the area used for this field experiment (Calonego and Rosolem 2010). Poor aeration can negatively influence optimal growth of crops by restricting diffusion and gas exchange. Although an increase in soil macroporosity in the treatments involving the materials for soil acidity correction and production systems with off-season crops was measured in the top $0.2 \mathrm{~m}$, none of these treatment combinations had macroporosity values below $10 \%$, which has been established as the critical limit to avoid limitations in soil aeration (de Jong Van Lier 2010).

\section{Conclusions}

Near-surface soil physical properties measured in this study were independently affected by production system and acidneutralising soil amendment, but were not interactively affected 
by both imposed treatment factors. Results of this study demonstrated that certain near-surface soil physical properties (i.e. BD, macroporosity, MWD, MGD, and ASI) can be improved in a no-tillage soybean-maize-rice rotation using a forage crop in the off-season and with the addition of acid-neutralising soil amendments. Compared with the fallow-crop system, the forage-crop production system offers a large amount of annual aboveground and belowground crop residues that are returned to the soil as valuable organic matter to positively affect soil physical properties and improve aggregation. In regions with highly weathered, SOM-depleted, acidic Oxisols, any soil or crop management practices that improve soil physical properties and aggregation will likely contribute to sustaining long-term soil and crop productivity.

\section{Acknowledgements}

The authors thank the São Paulo Research Foundation (FAPESP) for providing financial support (Registry numbers: 2006/01705-4, 2009/ $10232-0$, and 2009/05066-4).

\section{References}

Albuquerque JA, Bayer C, Ernani PR, Mafra AL, Fontana EC (2003) Aplicação de calcário e fósforo e estabilidade da estrutura de um solo ácido. Revista Brasileira de Ciência do Solo 27, 799-806. [In Portuguese] doi:10.1590/S0100-06832003000500004

Baver LD, Gardner WH, Gardner WR (1972) 'Soil physics.' 4th edn. (Wiley: New York)

Bayer C, Mielniczuk J (2008) Dinâmica e função da matéria orgânica. In 'Fundamentos da matéria orgânica do solo: ecossistemas tropicais e subtropicais'. (Eds G de A Santos, LS da Silva, LP Canellas, FA de O Camargo) pp. 7-18. (Metrópole: Porto Alegre) [in Portuguese]

Blanco-Canqui H, Stone LR, Stahlman PW (2010) Soil response to long-term cropping systems on an Argiustoll in the central Great Plains. Soil Science Society of America Journal 74, 602-611. doi:10.2136/ sssaj2009.0214

Bortoluzzi EC, Poleto C, Baginski ÁJ, da Silva VR (2010) Aggregation of subtropical soil under liming: a study using laser diffraction. Revista Brasileira de Ciência do Solo 34, 725-734. doi:10.1590/S0100-0683 2010000300014

Calonego JC, Rosolem CA (2008) Estabilidade de agregados do solo após manejo com rotações de culturas e escarificação. Revista Brasileira de Ciência do Solo 32, 1399-1407. [In Portuguese] doi:10.1590/S010006832008000400004

Calonego JC, Rosolem CA (2010) Soybean root growth and yield in rotation with cover crops under chiseling and no-till. European Journal of Agronomy 33, 242-249. doi:10.1016/j.eja.2010.06.002

Calonego JC, Borghi E, Crusciol CAC (2011) Intervalo hídrico ótimo e compactação do solo com cultivo consorciado de milho e braquiária. Revista Brasileira de Ciência do Solo (Online) 35, 2183-2190. [In Portuguese] doi:10.1590/S0100-06832011000600033

Camargo OA, Alleoni LRF (1997) 'Compactação do solo e o desenvolvimento das plantas.' (ESALQ: Piracicaba) [in Portuguese]

Camargo OA, Moniz AC, Jorge JA, Valadares JMAS (2009) 'Métodos de análise química, mineralógica e física de solos do Instituto Agronômico de Campinas.' (Instituto Agronômico: Campinas) [in Portuguese]

Castro GSA, Calonego CC, Crusciol CAC (2011) Propriedades físicas do solo em sistemas de rotação de culturas conforme o uso de corretivos da acidez. Pesquisa Agropecuária Brasileira 46, 1690-1698. [In Portuguese] doi:10.1590/S0100-204X2011001200015

Castro Filho C, Lourenço A, Guimarães MF, Fonseca ICB (2002) Aggregate stability under different soil management systems in a red latosol in the state of Parana, Brazil. Soil \& Tillage Research 65, 45-51. doi:10.1016/ S0167-1987(01)00275-6

Corrêa JC, Bull LT, Crusciol CAC, Moraes MH (2009) Alteração de atributos físicos em Latossolo com aplicação superficial de escória de aciaria, lama cal, lodos de esgoto e calcário. Revista Brasileira de Ciência do Solo 33, 263-272. [In Portuguese] doi:10.1590/S010006832009000200004

Costa F de S, Bayer C, Albuquerque JA, Fontoura SMV (2004) Calagem e as propriedades eletroquímicas e físicas de um Latossolo em plantio direto. Ciência Rural 34, 281-284. [In Portuguese] doi:10.1590/S010384782004000100045

Cunha E de Q, Balbino LC, Stone LF, Leandro WM, de Oliveira GC (2007) Influência de rotações de culturas nas propriedades físico-hídricas de um Latossolo Vermelho em plantio direto. Engenharia Agrícola 27, 665-674. [In Portuguese] doi:10.1590/S0100-69162007000400009

Dane JH, Hopmans JW (2002) Pressure plate extractor. In 'Methods of soil analysis. Physical methods'. (Eds JH Dane, C Topp) pp. 688-690. (Soil Science Society of America: Madison, WI)

Danielson RE, Sutherland PL (1986) Porosity. In 'Methods of soil analysis. Physical and mineralogical methods'. (Ed. A Klute) pp. 443-461. (American Society of Agronomy: Madison, WI)

de Jong Van Lier Q (2010) 'Física do solo.' (Sociedade Brasileira de Ciência do Solo: Viçosa) [in Portuguese]

De Maria IC, Castro OM, Dias HS (1999) Atributos físicos do solo e crescimento radicular de soja em Latossolo Roxo sob diferentes métodos de preparo do solo. Revista Brasileira de Ciência do Solo 23, 703-709. [In Portuguese] doi:10.1590/S0100-06831999000300025

Garcia RA, Rosolem CA (2010) Agregados em um Latossolo sob sistema plantio direto e rotação de culturas. Pesquisa Agropecuária Brasileira 45, 1489-1498. [In Portuguese] doi:10.1590/S0100-204X2010001 200021

Gardner WH (1986) Water content. In 'Methods of soil analysis. Physical and mineralogical methods'. 2nd edn. (Ed. A Klute) pp. 493-544. (American Society of Agronomy: Madison, WI)

Griève IC, Davidson DA, Bruneau PMC (2005) Effects of liming on void space and aggregation in an upland grassland soil. Geoderma 125, 39-48. doi:10.1016/j.geoderma.2004.06.004

Huang S, Peng XX, Huang QR, Zhang WJ (2010) Soil aggregation and organic carbon fractions affected by long-term fertilization in a red soil of subtropical China. Geoderma 154, 364-369. doi:10.1016/j.geoderma. 2009.11.009

Isbell R (2016). 'The Australian soil classification.' 2nd edn. (CSIRO Publishing: Collingwood, Vic.)

Kemper WD, Chepil WS (1965) Size distribution of aggregates. In 'Methods of soil analysis'. (Eds CA Black, DD Evans, JL White, LE Ensminger, FE Clark) pp. 499-510. (American Society of Agronomy: Madison, WI)

Kiehl EJ (1979) 'Manual de edafologia: relações solo - planta.' (Agronômica Ceres: São Paulo) [in Portuguese]

Rolim GS, Camargo MPB, Lania DG, Moraes JF (2007) Classificação climática de Köppen e de Thornthwaite e sua aplicabilidade na determinação de zonas agroclimáticas para o estado de são Paulo. Bragantia 66, 711-720. [In Portuguese] doi:10.1590/S0006-87052007 000400022

Salton JC, Mielniczuk J, Bayer C, Boeni M, Conceição PC, Fabrício AC, Macedo MCM, Broch DL (2008) Agregação e estabilidade de agregados do solo em sistemas agropecuários em Mato Grosso do Sul. Revista Brasileira de Ciência do Solo 32, 11-21. [In Portuguese] doi:10.1590/ S0100-06832008000100002

Santos CA, Lanças KP (1999) Projeto e construção de um penetrômetro hidráulico-eletrônico. Energia na Agricultura 14, 55-61. [In Portuguese]

Seta AK, Karathanasis AD (1996) Water dispersible colloids and factors influencing their dispersibility from soil aggregates. Geoderma 74, 255-266. doi:10.1016/S0016-7061(96)00066-3 
Silva RH, Rosolem CA (2001) Crescimento radicular de espécies utilizadas como cobertura decorrente da compactação do solo. Revista Brasileira de Ciência do Solo 25, 253-260. [In Portuguese] doi:10.1590/S010006832001000200001

Silva IF, Mielniczuk J (1997) Ação do sistema radicular de plantas na formação e estabilização de agregados do solo. Revista Brasileira de Ciência do Solo 21, 113-117. [In Portuguese] doi:10.1590/S010006832008000100002

Stone LR, Schlegel AJ (2010) Tillage and crop rotation phase effects on soil physical properties in the West-Central Great Plains. Agronomy Journal 102, 483-491. doi:10.2134/agronj2009.0123

Tavares Filho J, Barbosa GM, Ribon AA (2010) Physical properties of dystrophic Red Latosol (Oxisol) under different agricultural uses. Revista Brasileira de Ciência do Solo 34, 925-933. doi:10.1590/ S0100-06832010000300034

van Raij B, de Andrade JC, Cantarella H, Quaggio JA (Eds) (2001) ‘Análise química para avaliação da fertilidade de solos tropicais.' (Instituto Agronômico: Campinas) [in Portuguese]
Wendling B, Jucksch I, Mendonça E. de S., Neves JCL (2005) Carbono orgânico e estabilidade de agregados de um Latossolo Vermelho sob diferentes manejos. Pesquisa Agropecuária Brasileira 40, 487-494. [In Portuguese] doi:10.1590/S0100-204X2005000500010

Wohlenberg EV, Reichert JM, Reinert DJ, Blume E (2004) Dinâmica da agregação de um solo franco-arenoso em cinco sistemas de culturas em rotação e em sucessão. Revista Brasileira de Ciência do Solo $\mathbf{2 8}$, 891-900. [In Portuguese] doi:10.1590/S0100-06832004000500011

Yoder RE (1936) A direct method of aggregate analysis of soils and a study of the physical nature of erosion losses. Journal of the American Society of Agronomy 28, 337-351. doi:10.2134/agronj1936.000219620028000 $50001 \mathrm{x}$

Zonta E, da Brasil F, Goi SR, da Rosa MMT (2006) O sistema radicular e suas interações com o ambiente edáfico. In 'Nutrição mineral de plantas'. (Ed. MS Fernandes) pp. 7-52. (Sociedade Brasileira de Ciência do Solo: Viçosa) [in Portuguese] 